\title{
Changes in Soil Physical and Chemical Properties after a Coal Mine Subsidence Event in a Semi-Arid Climate Region
}

\author{
Yingga Wu, Xiaomei Gao, Dandan Zhou, Ruiping Zhou* \\ College of Geographical Science, Inner Mongolia Normal University, Hohhot 010022, China
}

Received: 15 June 2021

Accepted: 22 October 2021

\begin{abstract}
This study describes the effects of coal mine collapse on soil physical and chemical properties in the semi-arid Bulianta mining area of northwest China. Statistical analysis of soil data from 2006, 2012 and 2019 show systematic long term changes of soil physical and chemical properties in response to a 2004 subsidence event. Results show that soil moisture content increased while soil bulk density (SBD) decreased gradually with the passage of time. Samples from different years since the subsidence event showed no significant difference in soil $\mathrm{pH}(\mathrm{P}>0.05)$. The $0-5 \mathrm{~cm}$ soil layers showed the highest organic matter levels but values decreased with soil depth. The average organic matter content of soils in the subsided area increased with time since the subsidence event. Variation coefficients and average rate of change for available nitrogen (AN), available phosphorus (AP) and available potassium (AK) all decreased as contents tended to stabilize over time. Changes in soil physicochemical properties caused by subsidence represent long term economic, social and environmental costs. The results from this study demonstrate the benefits of early stage remediation or preemptive avoidance of risks posed by mine construction. They also provide references for long term monitoring of soil quality and restoration of mining areas.
\end{abstract}

Keywords: semi-arid area, soil physicochemical properties, rate of change, Bulianta Coal Mine

\section{Introduction}

Coal is the main source of energy in China and this mineral resource remains in high demand in spite of some of its drawbacks as a fossil fuel. Coal mining supports economic development and increases in national standard of living. Coal extraction has also transitioned from traditional open-pit mining to

*e-mail: rpzhou@126.com subsurface mining [1]. However, in the semi-arid region of northwest China, where soil and vegetation regimes are particularly fragile, subsurface mining has led to ground subsidence events that commonly attend this practice [2-4]. The scale and intensity of subsidence represents a significant environmental impact [5-6]. Soil is a critical component of the environment [7] and represents the resource most impacted by the subsidence. Surface collapse for example represents a catastrophic change in soil environment [8] from which an area may not recover on a given time scale. 
Critical changes in soil often appear through their physical and chemical properties [9]. Research paradigms treat these properties as proxies for soil quality and monitor them accordingly. Cui Gaoyang et al. [10] found that soil physical and chemical properties can improve with time as specifically indicated by the increase in soil capillary porosity, total porosity, field capillary water holding capacity, permeability rate, $\mathrm{pH}$ value, total potassium, available potassium and total phosphorus content. Results described in Guo Nan et al. [11] showed that soil physical and chemical properties change with different phytoremediation methods. Li $\mathrm{Xia}$ et al. [12] found that variation in soil organic matter (SOM), nitrogen and phosphorus reflected changes in microbial communities. Most studies of soil physicochemical properties focus on shorter time frames. Studies of long term variation in soil physical and chemical properties after a major perturbation like mine subsidence are relatively few. Bulianta Coal Mine, located in the semi-arid environs of northwest China, is a subsurface mine developed by Shendong Coal Group. Areas above the mine experience persistent subsidence and ground collapse [13]. This study compared changes in soil physical and chemical properties after subsidence events associated with the subsurface mine. The study monitored these parameters sporadically over 15 years in order to determine trajectories and the range of variation in soil properties associated with subsidence and restoration in a semi-arid climate region.

\section{Materials and Methods}

\section{Study Area}

The Bulianta Mine Area is located in Wulanmulun Town, Yijin Horo Banner, Ordos City, Inner Mongolia $\left(109^{\circ} 45^{\circ}-110^{\circ} 40^{\prime} \mathrm{E}, 38^{\circ} 50^{\circ}-39^{\circ} 50^{\prime} \mathrm{N}\right)$. The land rests at 1100-1300 m elevation and experiences annual average temperature of $6^{\circ} \mathrm{C}$. The study area receives average annual rainfall of $358.2 \mathrm{~mm}$ and experiences 67.8 annual average precipitation days which concentrate over 6-9 months of the year. Annual evaporation reaches $2838.7 \mathrm{~mm}$ and thus conforms to typical temperate continental monsoon climate patterns. The terrain of the study area consists of hills and gullies with higher elevations to the west. The area categorizes as arid and semi-arid zones of steppe to desert steppe climate types. The main soil types in the study area are aeolian sand soil and cotton sand soil. The main vegetation types are sandophytic vegetation such as Salix cheilophila, Artemisia ordosica Krasch and Psammochloa villosa etc.. These mainly grow upon fixed and semi-fixed sand land.

\section{Sample Sites and Sampling}

The sample site selected for this experiment collapsed in 2004. Soil samples were collected and analyzed in April 2006, April 2012 and July 2019. Samples with similar underlying surface conditions were collected and analyzed over different years (land at an average elevation of $1090 \mathrm{~m}, 11^{\circ}-14^{\circ}$ slope, same vegetation types). Areas with similar soil conditions but not subsiding or at risk of subsidence were selected for control samples. Table 1 lists parameters associated with different sample sites over the 15 year time frame of the study. A $1 \times 1 \mathrm{~m}^{2}$ area was sampled at various depths up to $1 \mathrm{~m}$ at each site. Within the area, a multipoint sampling method sampled different soil depths of $0-5 \mathrm{~cm}, 0-20 \mathrm{~cm}, 20-60 \mathrm{~cm}$ and $60-100 \mathrm{~cm}$.

\section{Laboratory Analysis and Data Processing}

Of the soil physical properties, the soil moisture content was measured by drying methods. The soil bulk density (SBD) was determined by the ring knife method. Of the soil chemical properties, soil $\mathrm{pH}$ was

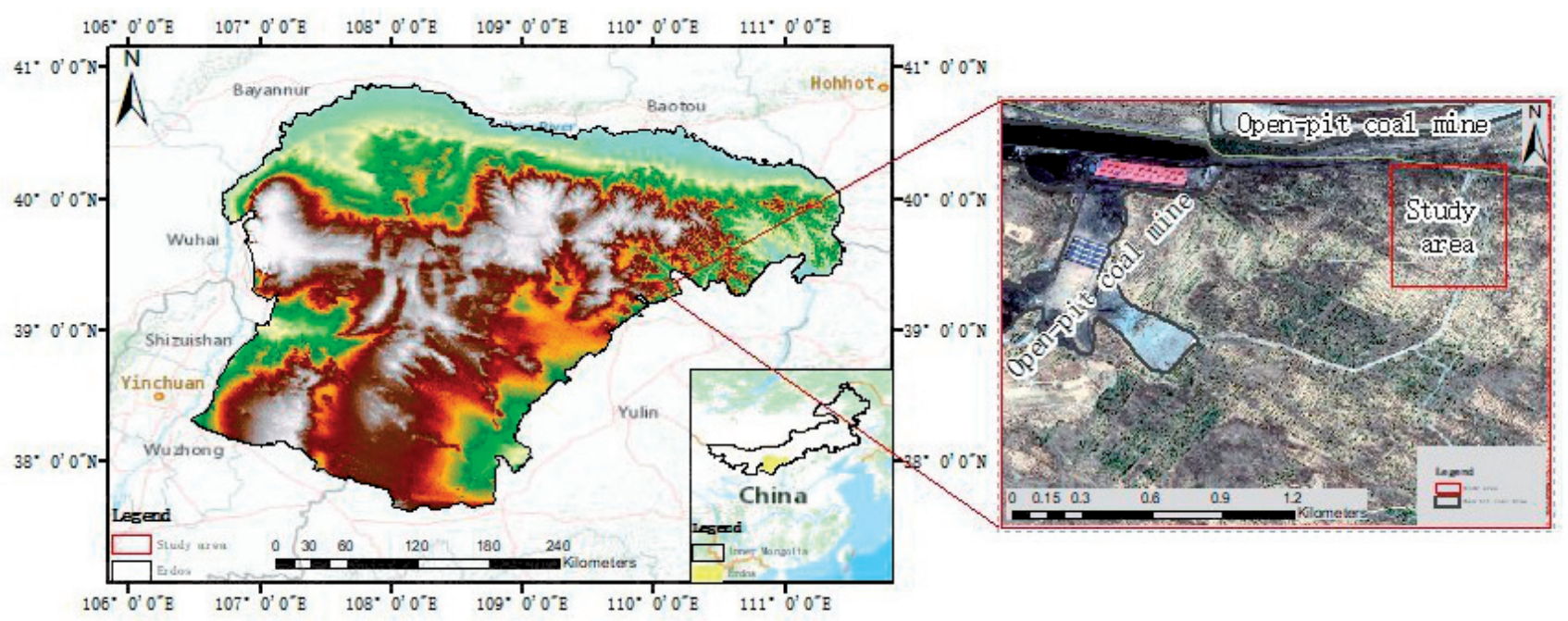

Fig. 1. Location and map of the study area. 
Table 1. Basic information on sample sites.

\begin{tabular}{|c|c|c|c|c|}
\hline Sample type & No subsidence & 2 years after the subsidence & 8 years after the subsidence & 15 years after the subsidence \\
\hline Subsidence time & No subsidence & 2006 & 2012 & 2019 \\
\hline Elevation & $1100 \mathrm{~m}$ & $1190 \mathrm{~m}$ & $1045 \mathrm{~m}$ & $1032 \mathrm{~m}$ \\
\hline Slope & $13^{\circ}$ & $13^{\circ}$ & $12^{\circ}$ & $13^{\circ}$ \\
\hline Soil type & Sand soil & Sand soil & Sand soil & Sand soil \\
\hline Vegetation types & \multicolumn{3}{|c|}{ Salix cheilophila, Artemisia ordosica Krasch and Psammochloa villosa } \\
\hline
\end{tabular}

measured by the potential method using a PXJ-1C type $\mathrm{pH}$ meter. Soil organic matter (SOM) was measured by the potassium dichromate external heating method. Soil available nitrogen (AN) was measured by the Kjeldahl method. Soil available phosphorus (AP) was measured using a $0.5 \mathrm{ml} \mathrm{L}{ }^{-1} \cdot \mathrm{NaHCO}_{3}$ extraction method. Soil available potassium (AK) was measured by flame photometric method.

Data were processed in Microsoft Excel with statistical calculations carried out in SPSS 25.0. Origin Pro 9.1 was used was used to plot graphs. Statistics included standard variance estimates, and significance tests for the difference of soil physicochemical properties before and after subsidence. Unless otherwise indicated, significance estimates are reported for the $\mathrm{P}<0.05$ interval. The rate of change $(\mathrm{MN})$, coefficient of variation $(\mathrm{CV})$, mean and standard deviation $(\mathrm{SD})$ of soil physical and chemical property factors such as soil moisture content, soil bulk density and available nitrogen were calculated according to the following formulas:

$$
\begin{gathered}
Y=\frac{X_{a}-X_{b}}{X_{b}} \times 100 \% \\
C V=\frac{\text { Stdev }}{\text { Mean }} \\
\text { Mean }=\frac{\left(x_{1}+x_{2}+x_{3}+\cdots+x_{n}\right)}{n} \\
\text { Stdev }=\sqrt{\frac{\sum_{i=1}^{n} x_{i}-\text { Mean }}{n}}
\end{gathered}
$$
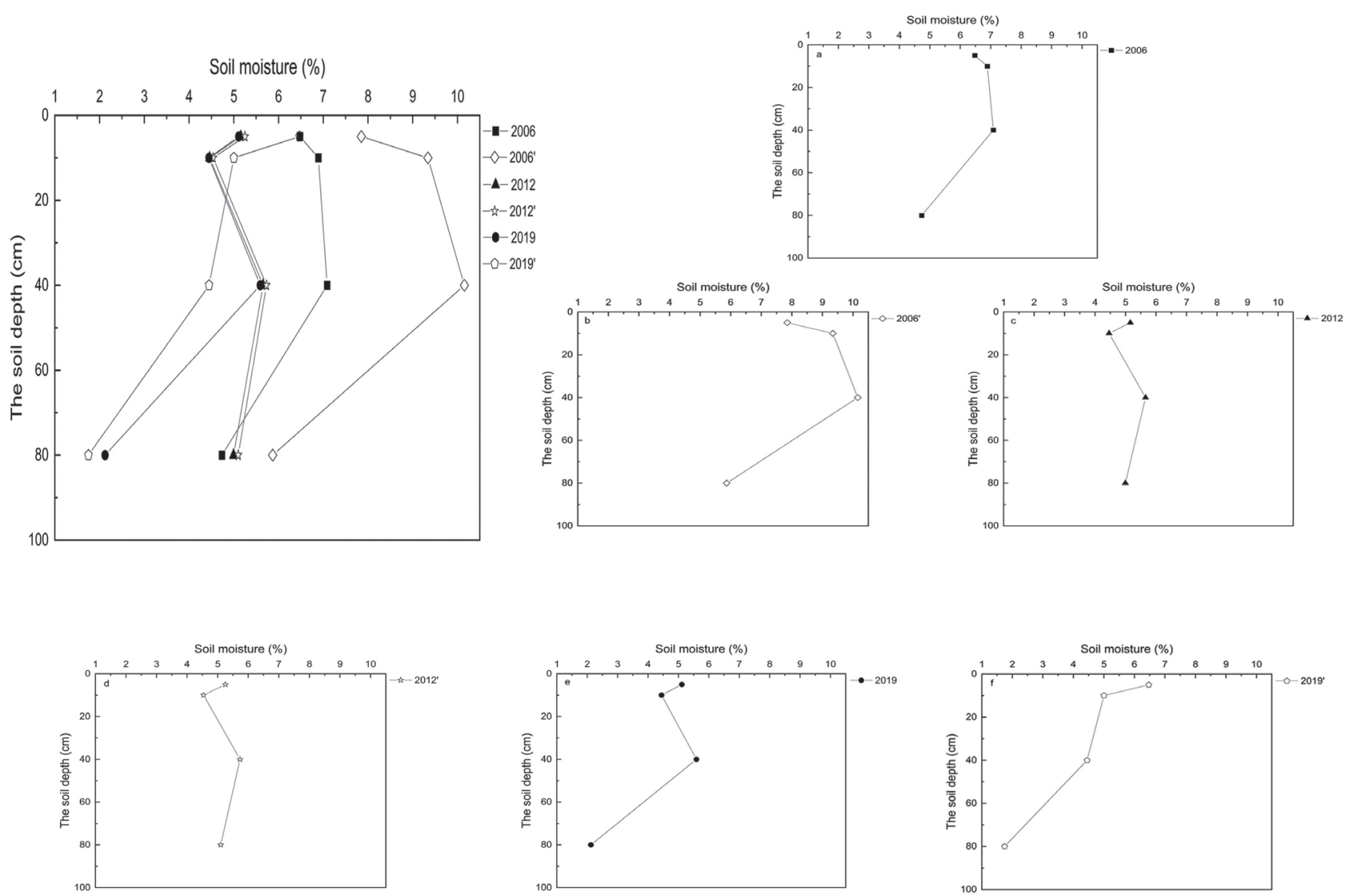

Fig. 2 Changes in soil moisture content for the subsided area and control area samples from 2006 to 2019. 
In these equations, $Y$ is the rate of change in soil physicochemical properties, $X_{a}$ represents the soil physicochemical properties before the change, $X_{b}$ represents the physicochemical properties after the change. These represent variables. The term $C V$ represents the coefficient of variation, Stdev, the standard deviation of data, Mean, the mean value, $n$ the total number of data points, $i$ the specific datum in the series, $x_{i}$ the $i$ th datum and $x_{n}$ the $n$th datum.

\section{Results}

\section{Influence of Subsidence on Physical Properties}

\section{Changes in Soil Moisture Content}

Soil moisture content refers to the volume ratio of water content in soil and is calculated as the ratio of soil water weight to the weight of dried soil [14]. Fig. 2 shows the soil moisture content of samples from subsided areas in 2006, 2012 and 2019 and for control samples (2006, 2012 and 2019). These show that the moisture content in the $0-5 \mathrm{~cm}$ soil layer of the subsided area fell significantly below that of the control area. In terms of its vertical distribution, soil moisture content decreases with increasing soil depth. The $0-5 \mathrm{~cm}$ samples gave the highest soil moisture content, while the $60-100 \mathrm{~cm}$ samples gave the lowest soil moisture content. As shown in Table 2, soil moisture content did not vary with time following the subsidence event. Differences in soil moisture content between the subsided area and the control area gradually decrease however over the years. The coefficient of variation estimated for soil moisture content also decreased with time indicating that this parameter tends to stabilize with time.

\section{Changes in Soil Bulk Density}

Soil bulk density (SBD) is the ratio of the mass of a given volume of soil after drying relative to its volume before drying [15]. As shown in Fig. 3, SBD did not significantly vary among samples according to depth. Control sample SBD decreased over time and generally exceeded values measured from subsided area samples except in 2019. From the perspective of years transpired since the subsidence event, SBD values measured from samples collected in different years ranked as $2006>2012>2019$. Coefficients of variation in SBD for different years ranked as $2006<2012<2019$ (Table 2). These indicate that variation in SBD increases while SBD values themselves gradually decrease with the passage of time since the subsidence event. Control samples showed similar trends. The SBD values from the subsided area gradually converge towards values measured from control areas.

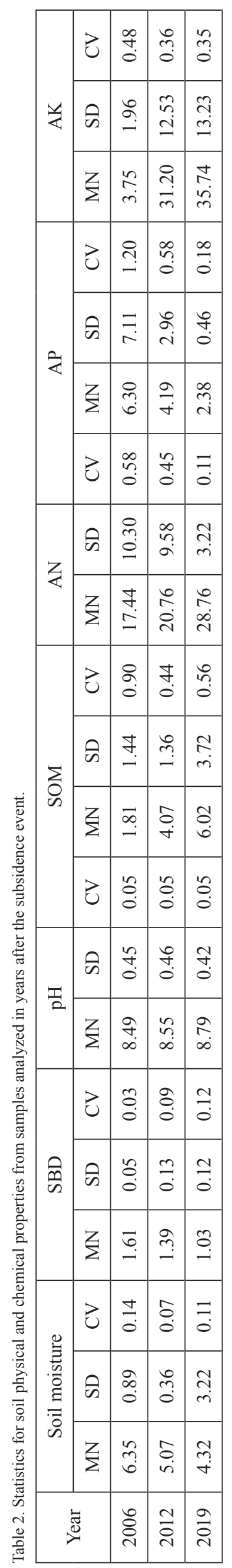



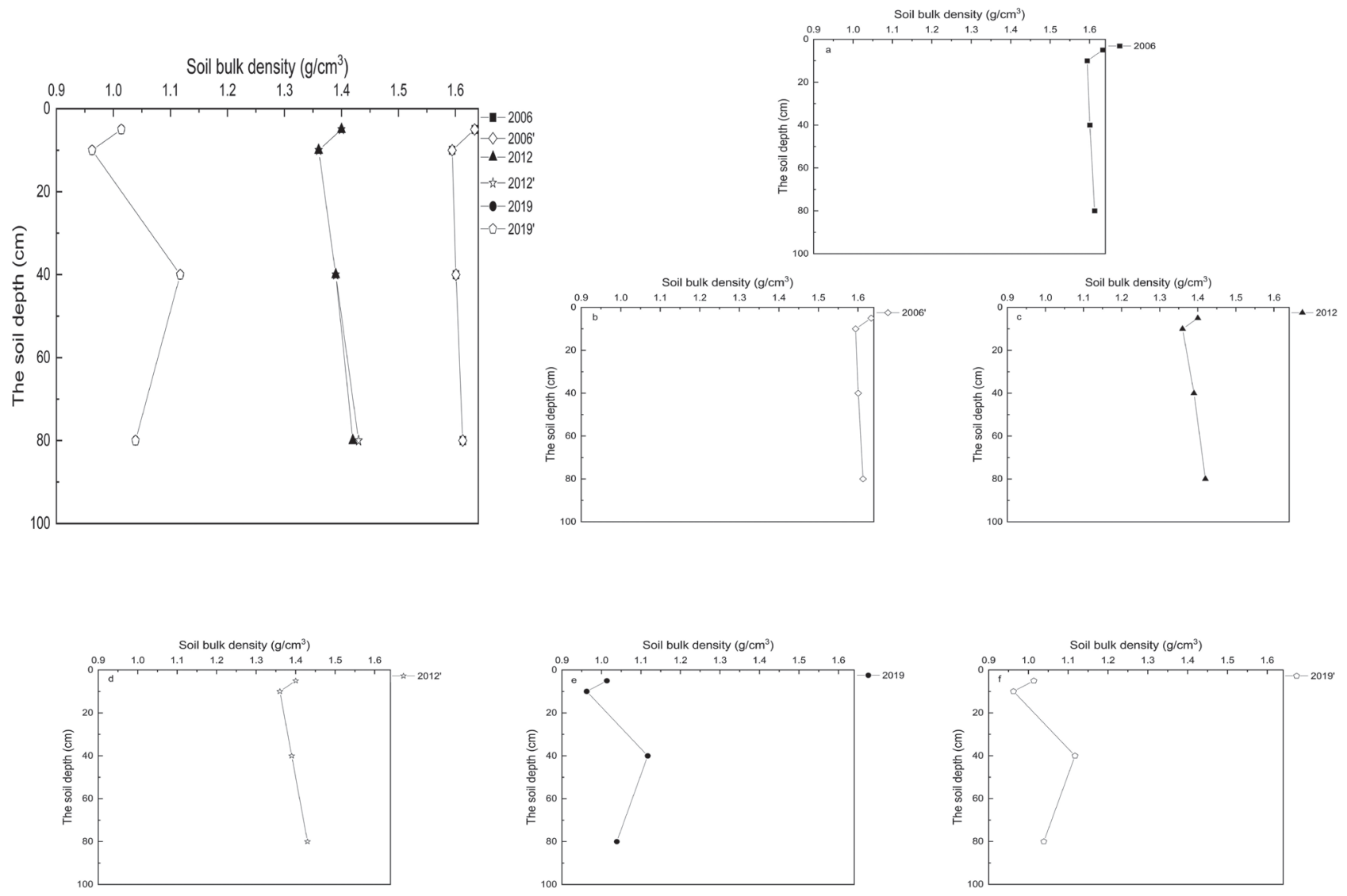

Fig. 3. Changes in SBD from subsided area and control area samples from 2006 to 2019.
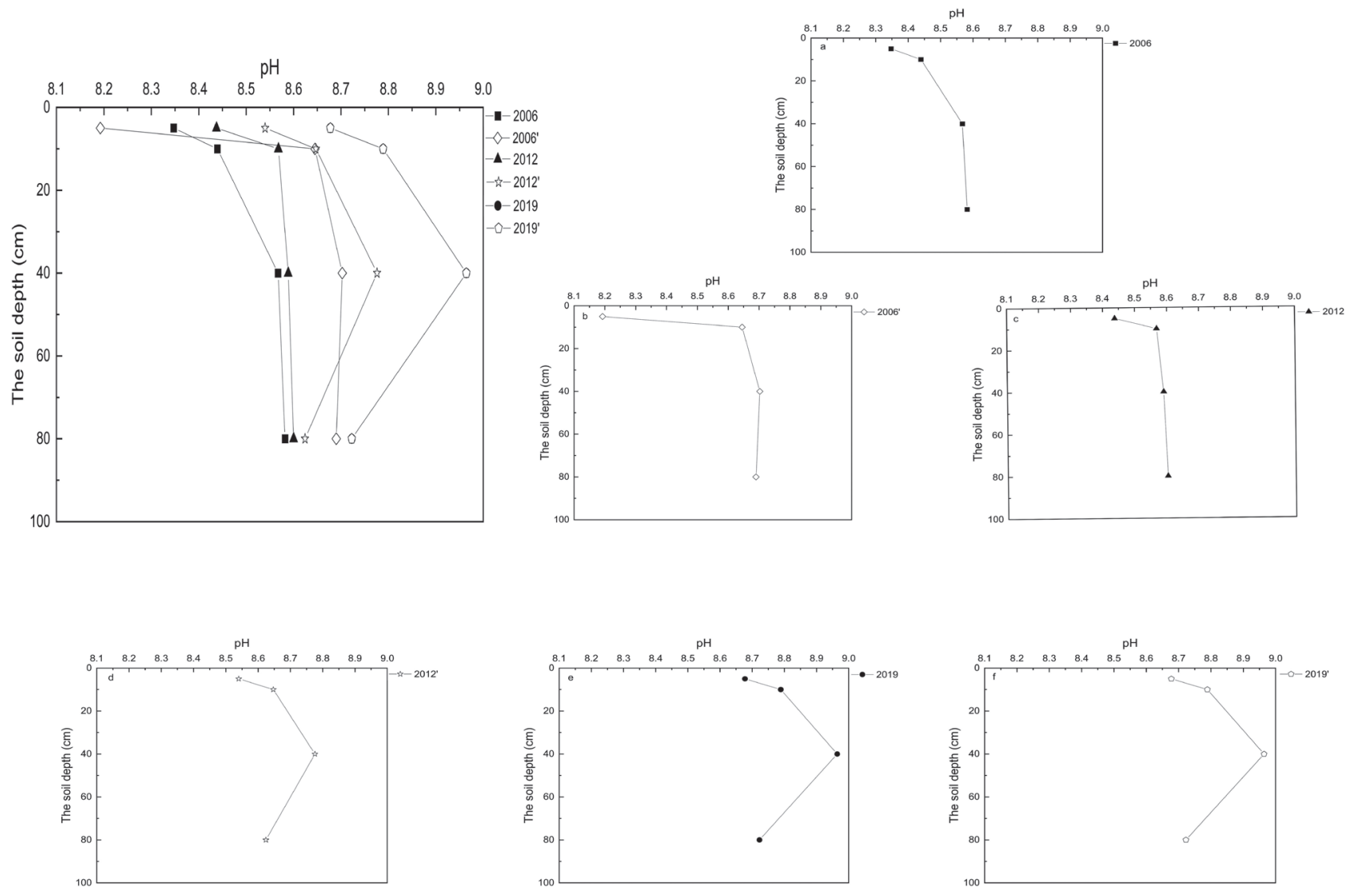

Fig. 4. Soil pH values for samples collected from the subsided area and the control area from 2006 to 2019. 


\section{Influence of Subsidence on Chemical Properties}

\section{Changes in Soil pH Values}

Soil $\mathrm{pH}$ can influence plant growth and soil fertility [16]. Samples collected from the study area before and after the subsidence event (Fig. 4) gave soil $\mathrm{pH}$ values of about 8 . These did not vary significantly between different soil layers. A sample from the $0-5 \mathrm{~cm}$ layer gave the minimum soil $\mathrm{pH}$ value observed, and values showed gradual increase with depth. Samples collected from the subsided area at all depths in 2006 and 2012 gave soil $\mathrm{pH}$ values below those measured from the control area. Samples collected from the subsided area in 2019 gave higher $\mathrm{pH}$ values than corresponding samples from the control area. The $\mathrm{pH}$ values from samples collected from the subsided area in 2019 gradually increased with depth.

\section{Changes in Soil Organic Matter}

Along with rock and mineral fragments, soil organic matter (SOM) represents an important component of soil solids. This material improves soil productivity. Vegetation can also strongly influence soil physicochemical properties [17]. Fig. 5 shows that the $0-5 \mathrm{~cm}$ layer samples gave the highest SOM content. Deeper samples gave systematically lower SOM values. Control group samples generally gave higher SOM values than those measured in samples from the subsided area across all years. The $0-5 \mathrm{~cm}$ sample collected from the subsided area in 2019 gave the highest overall SOM value followed by samples collected in 2012 and 2006. SOM also decreased with increasing soil depth but the decline was not large. Table 2 lists variation coefficients for SOM. These initially decrease and then increase with the passage of time since the subsidence event. These results indicate that the subsidence significantly disturbed organic matter in the soil and restoration to original levels requires more than a decade's time.

\section{Changes in Soil Available Nitrogen}

Soil available nitrogen (AN) can be easily lost or absorbed by plants. Available nitrogen also generally occurs in lower concentrations than other elements in soils [18]. As shown in Fig. 6, samples from the 0-5 cm soil layer exhibited higher AN values than those measured from other soil layers. Soil AN decreases with increasing depth. The $0-5 \mathrm{~cm}$ sample from the subsided areas as collected over different years gave AN values ranked as follows: 2019>2012>2006. Table 2 shows that AN variation coefficients also decrease with time indicating stabilization with the passage of time since the subsidence event. By 2019, AN content shows very little change and the content in any soil layer exceeded that measured from earlier years. The AN content in 2012 samples was lower than that measured from
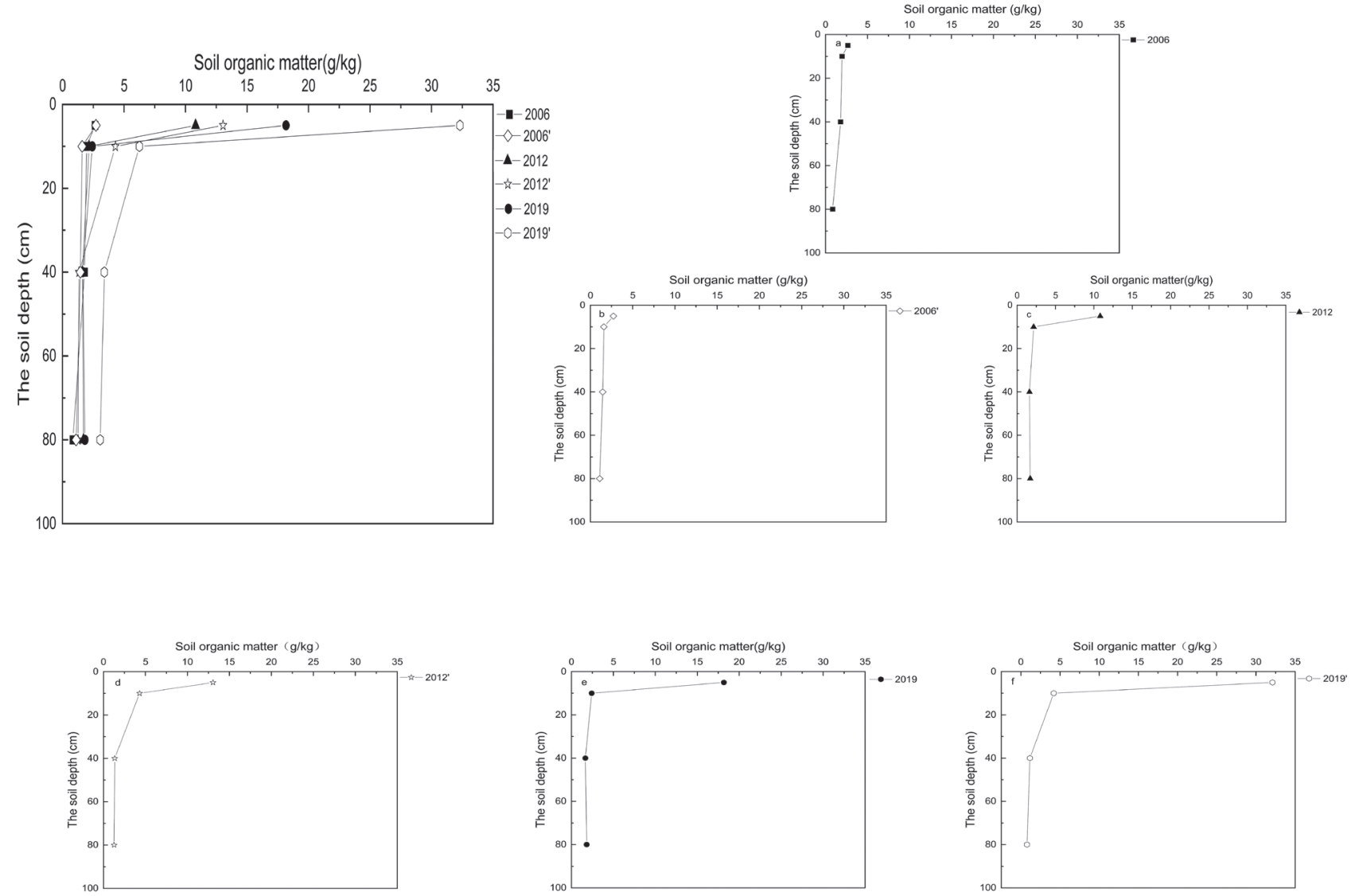

Fig. 5. Changes in SOM for samples from the subsided and control areas collected from 2006 to 2019. 

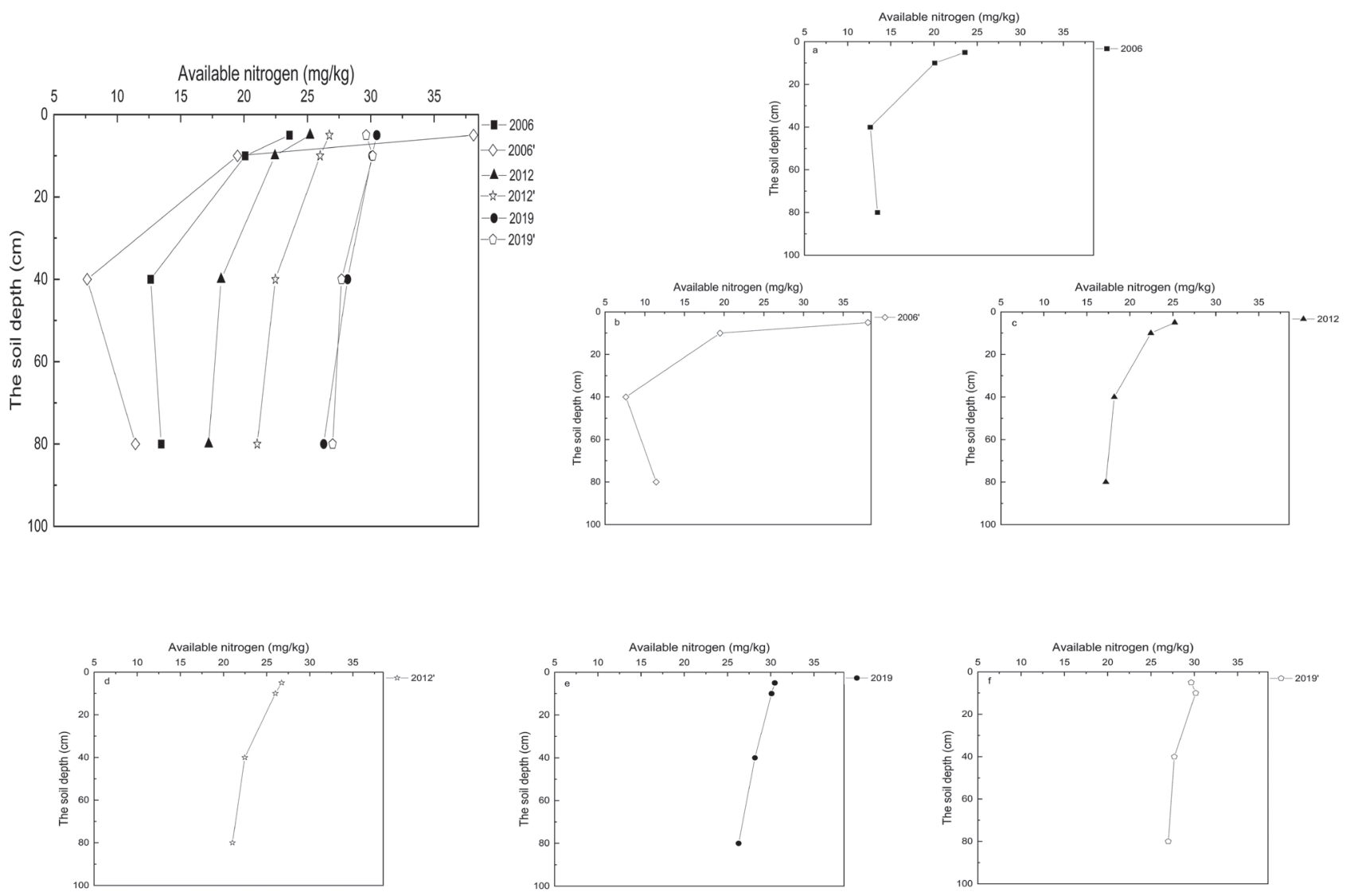

Fig. 6. Changes in soil AN for samples collected in the subsidence area and control area from 2006 to 2019.
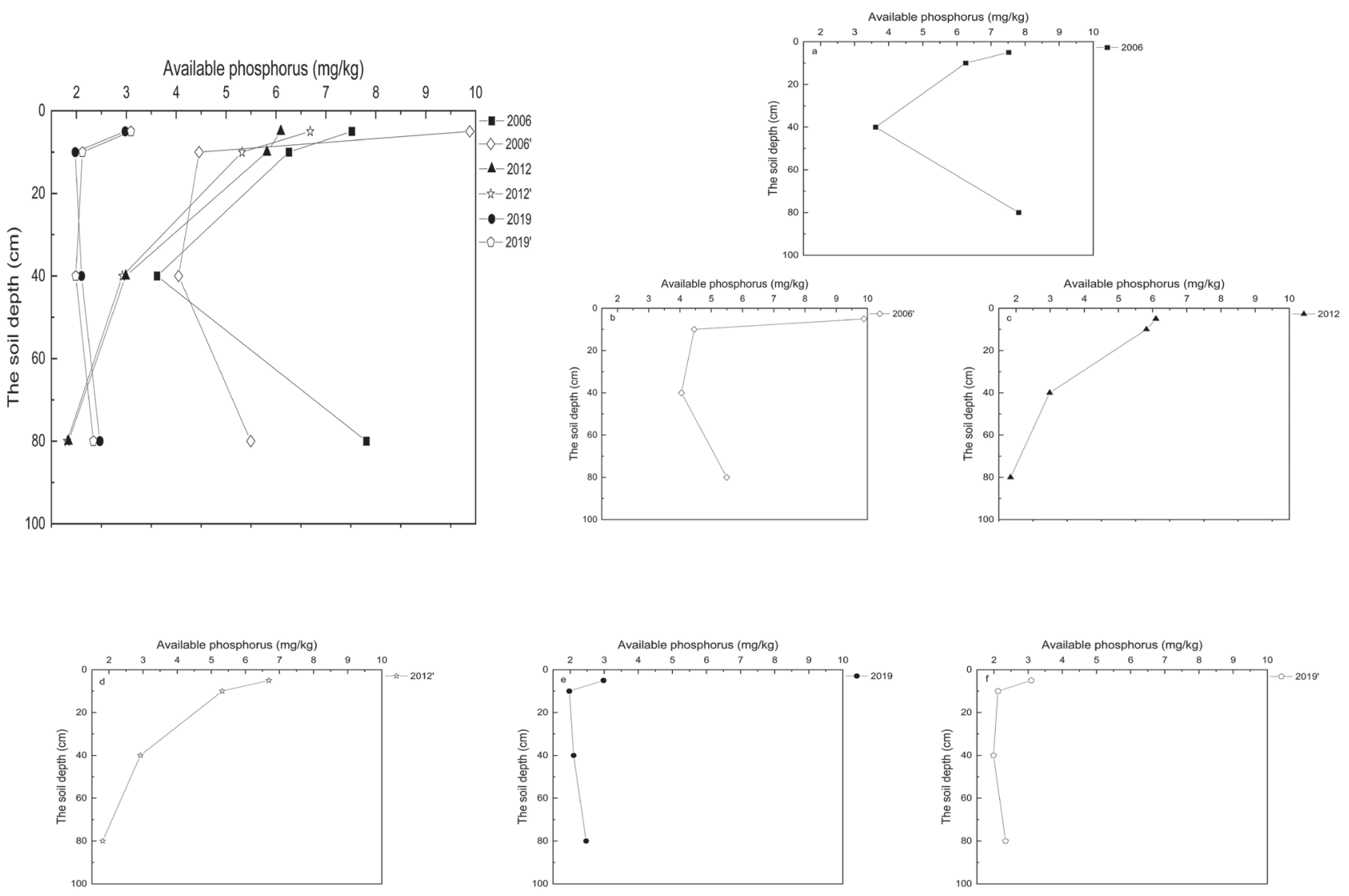

Fig. 7. Changes in soil AP for the subsided area and control area samples from 2006 to 2019. 
2019 samples but higher than that measured from 2006 samples. The $0-5 \mathrm{~cm}$ samples collected in 2006 and 2012 showed no significant difference in AN. However, AN content declined faster with depth in 2006 samples than in 2012 samples.

\section{Changes in Soil Available Phosphorus}

Phosphorus content provides information on soil nutrient composition [19] and available phosphorus (AP) is the part of soil that can be easily absorbed and utilized by plants [20]. As shown in Fig. 7, the 0-5 $\mathrm{cm}$ layer contained higher AP than other soil layers. The $0-5 \mathrm{~cm}$ layer samples from the subsided areas ranked as follows in terms of AP content for different years: $2019<2012<2006$. The 2019 samples exhibited significantly lower AP content across all layers than that measured for other years. Variation coefficients for AP in samples collected over different years (Table 2) ranked as follows: $2019<2012<2006$. Variation in soil AP thus became smaller as time passed since the subsidence event indicating that AP content gradually stabilizes with time.

\section{Changes in Soil Available Potassium}

A strong correlation frequently exists between available potassium (AK) and potassium uptake by plants. Plants can directly absorb potassium [20] which serves an essential element in photosynthesis, starch synthesis and sugar conversion. Potassium and by extension, AK, is thus an important parameter for soil fertility [21]. As shown in Fig. 8, the $0-5 \mathrm{~cm}$ samples exhibited the highest AK values measured for different years and values generally decrease with depth. The $0-5 \mathrm{~cm}$ layer samples collected over different years ranked as $2019<2012<2006$ in terms of their AK values. Samples from deeper soil layers collected over different years ranked as 2019>2012>2006 in terms of AK. The AK content did not appear to change much in early years after the collapse but increased rapidly in later years. Variation coefficients for AK declined over the years such that the variation coefficients for 2012 and 2019 barely differed from each other. This indicates that AK content stabilizes as the soil recovered from the subsidence event.

\section{Discussion}

\section{Effects of Subsidence on Soil Physical Properties}

Subsidence influences soil physicochemical properties which in turn influence soil quality and growth of surrounding vegetation. However, critical soil parameters do appear to recover with the passage
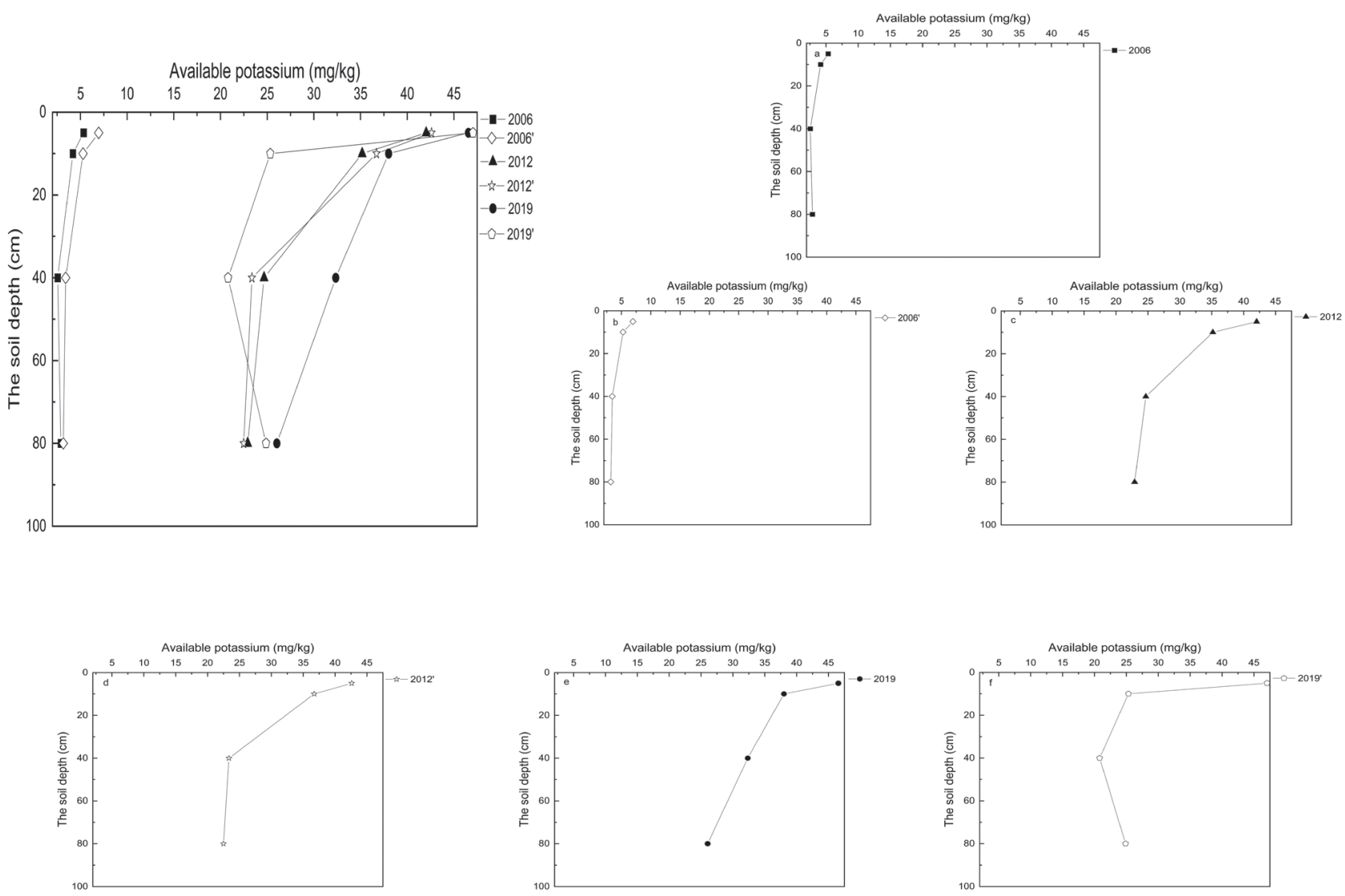

Fig. 8. Changes in soil AK for samples from the subsided area and control area from 2006 to 2019. 
of time since the subsidence event or with reclamation techniques such as mining while recovering [22].

As shown in Table 3, samples from the $0-5 \mathrm{~cm}$ soil layer showed the smallest change in moisture in 2006, while the $60-100 \mathrm{~cm}$ samples showed the largest change in moisture. The variation increased with soil depth. Rates estimated from 2012 samples did not significantly differ among soil layers, while the change in moisture for 2019 samples did differ significantly among soil layers. Table 4 shows that the average rate of change in moisture content from 2006 samples significantly exceeded that estimated from 2012 and 2019 samples. Meanwhile, moisture did not significantly differ in 2012 and 2019 samples. This indicates that the difference between the subsided area and the nonsubsided (control) areas was large in 2006 but smaller in 2012 and 2019. With the passage of time since the subsidence event, differences become smaller and smaller as the soil gradually recovers. Zang Yintong [23] reported that loss of soil moisture primarily reflects the development of soil cracks and structural loosening caused by surface failure. In describing why soil moisture content measured from samples associated with a longer collapse period exceeded that associated with a shorter collapse period, Han $\mathrm{Yu}$ [24] suggested that the filling of original surface cracks by sand and iron sheets formed by surface vegetation inhibited the evaporation of water.

Table 3 shows that the SBD varies systematically in samples from different years since the collapse event. Variation between shallower and deeper layers initially increased and then decreased such that the 60-100 $\mathrm{cm}$ samples showed the smallest change. Table 4 lists the average rate of change in SBD for different years since the subsidence event and shows that values also initially increased and then decreased to give the lowest value in 2019, followed by 2006, and then the highest value in 2012. Soil bulk density appears to have declined and then rebounded in years since the subsidence event.

Several studies [25-26] have found that SBD varies with porosity. The early stage of subsidence destroys soil structure. The loosening of the soil influences porosity. With the lapse of time since the subsidence event, the porosity changes little while the bulk density decreases.

\section{Effects of Subsidence on Soil Chemical Properties}

Results from this study showed that soil $\mathrm{pH}$ values did not vary to a large degree in samples from different layers collected from the same year (Table 3). The vertical variation in 2006 samples resembled that from 2012 samples. The 2019 samples exhibited the smallest degree of variation. A previous study has shown [27] that soil $\mathrm{pH}$ values reflect base-leaching and baseaccumulation in addition to climate and anthropogenic factors.
The study area occurs in a region subject to soil wind erosion with a stressed ecosystem and low overall soil organic matter. Soil organic matter has gradually increased since 2006 and attained their highest observed value in 2019 samples (Table 4). The 0-60 cm soil sample from 2006, the 20-100 cm sample from 2012 and the 20-100 cm sample from 2019 all exhibited lower organic matter than corresponding control samples. The $0-5 \mathrm{~cm}$ samples from the subsided area also showed significantly lower organic matter than samples from the control area. With the exception of 2006 samples, which showed declining organic matter, samples from other years showed increasing organic matter with time. Values however did not show recovery to original levels. Samples from 2006 exhibited negative rates of change in organic matter. Specifically, the $0-100 \mathrm{~cm}$ samples from the subsided and the control area showed only minor differences in organic matter content. Given the proximity of the subsidence event in time, effects may not have reached the deep soil layer. Data also indicate that organic matter primarily concentrated in surface soil layers. The 2006, 2012 and 2019 samples from the subsided area contained less organic matter than corresponding samples from the control area indicating that subsidence strongly impacted the soil surface. The 2006 sample from the deepest layer of the subsided area indicated organic matter levels much less impacted than those measured from the corresponding surface layer sample. Organic matter content did not differ significantly from that measured from the corresponding control group sample, and the average rate of change was negative. Many studies have shown that declining organic matter in soil reflects oxidation processes, soil erosion and the increase of soil permeability [28]. These processes accelerate organic matter decomposition [29] and result in lower organic matter values. The study area experiences considerable wind erosion and exhibited lower organic matter values after the subsidence event. With the passage of time since the event, soil organic matter increased to a certain extent but may not recover to its original levels.

Some studies [25] suggest that soil chemical parameters such as SOM and AN not only decline over the first 1-5 years since the subsidence event but will also show further variation over extended recovery periods. Another study has suggested that while soil chemical properties of the subsided area initially fell below those measured from the control area, available nutrients such as AN tend to generally rebound [30].

Previous studies have found that coal mine subsidence has a significant impact on soil AN, AP and AK [31] with greater impacts on shallower layers relative to deeper layers. The present study found that AN, AP and AK declined in subsided area samples with both depth and time since the subsidence event. For the $0-5 \mathrm{~cm}$ samples, AN, AP and AK levels ranked as follows for years since the subsidence event: $2006>2012>2019$. Samples from the subsided areas showed a lesser degree of variation 
Table 3. Differences relative to control area samples in soil layer parameters for different years (unit: \%).

\begin{tabular}{|c|c|c|c|c|c|c|c|c|}
\hline Year & $\begin{array}{l}\text { Physicochemical property } \\
\text { The soil depth }(\mathrm{m})\end{array}$ & Soil moisture & SBD & $\mathrm{pH}$ & SOM & $\mathrm{AN}$ & AP & $\mathrm{AK}$ \\
\hline \multirow{4}{*}{2006} & $0-5$ & 14.39 & 3.37 & -1.85 & 2.78 & 61.62 & 31.47 & 30.19 \\
\hline & $0-20$ & 35.56 & 4.43 & 2.44 & -18.70 & -3.03 & -28.78 & 26.03 \\
\hline & $20-60$ & 43.27 & -2.02 & 1.58 & -19.03 & -39.62 & 11.96 & 33.69 \\
\hline & $60-100$ & 23.97 & -4.62 & 1.26 & 31.08 & -15.04 & -29.67 & 9.13 \\
\hline \multirow{4}{*}{2012} & $0-5$ & 1.80 & 15.71 & 1.22 & 20.63 & 6.04 & 9.67 & 1.36 \\
\hline & $0-20$ & 1.80 & 18.38 & 0.92 & 99.38 & 15.90 & -8.55 & 4.40 \\
\hline & $20-60$ & 1.34 & 18.71 & 2.18 & -16.63 & 23.51 & -2.19 & -5.29 \\
\hline & $60-100$ & 2.12 & 12.32 & 0.28 & -25.54 & 22.24 & -1.51 & -1.88 \\
\hline \multirow{4}{*}{2019} & $0-5$ & 26.58 & -9.21 & -7.23 & 76.71 & -2.72 & 3.82 & 1.07 \\
\hline & $0-20$ & 12.56 & 4.16 & -4.89 & 73.43 & 0.20 & 7.21 & -33.36 \\
\hline & $20-60$ & -20.47 & -11.36 & -6.95 & -30.88 & -1.70 & -5.53 & -35.63 \\
\hline & $60-100$ & -17.54 & -9.75 & -5.40 & -57.06 & 2.68 & -5.25 & -4.46 \\
\hline
\end{tabular}

Table 4. Rate of change averaged over all depths for different years and soil parameters (unit: \%).

\begin{tabular}{|c|c|c|c|c|c|c|c|}
\hline Year & Soil moisture & SBD & $\mathrm{pH}$ & SOM & $\mathrm{AN}$ & AP & $\mathrm{AK}$ \\
\hline 2006 & 29.99 & 0.29 & 0.87 & -5.15 & 9.88 & -5.24 & 25.55 \\
\hline 2012 & 1.75 & 16.25 & 1.15 & 22.54 & 15.89 & -0.01 & 0.31 \\
\hline 2019 & 2.31 & -6.81 & -6.12 & 58.86 & -0.47 & -0.01 & -17.40 \\
\hline
\end{tabular}

Table 5. Soil physical and chemical properties as measured in different layers.

\begin{tabular}{|c|c|c|c|c|c|c|c|c|}
\hline Year & $\begin{array}{l}\text { Physicochemical } \\
\text { property } \\
\text { depth }(\mathrm{m})\end{array}$ & $\begin{array}{c}\text { Soil } \\
\text { moisture } \\
\%\end{array}$ & $\begin{array}{c}\mathrm{SBD} \\
\left(\mathrm{g} / \mathrm{cm}^{3}\right)\end{array}$ & $\mathrm{pH}$ & $\begin{array}{l}\text { SOM } \\
(\mathrm{g} / \mathrm{kg})\end{array}$ & $\begin{array}{c}\mathrm{AN} \\
(\mathrm{mg} / \mathrm{kg})\end{array}$ & $\begin{array}{c}\text { AP } \\
(\mathrm{mg} / \mathrm{kg})\end{array}$ & $\begin{array}{c}\mathrm{AK} \\
(\mathrm{mg} / \mathrm{kg})\end{array}$ \\
\hline \multirow{4}{*}{2006} & $0-5$ & $6.67 \pm 0.26 \mathrm{ab}$ & $1.63 \pm 0.046 \mathrm{a}$ & $8.35 \pm 0.46 \mathrm{a}$ & $2.65 \pm 2.04 \mathrm{a}$ & $23.58 \pm 10.91 \mathrm{a}$ & $7.52 \pm 7.06 \mathrm{a}$ & $4.98 \pm 3.58 \mathrm{a}$ \\
\hline & $0-20$ & $6.89 \pm 0.95 \mathrm{ab}$ & $1.60 \pm 0.048 \mathrm{a}$ & $8.44 \pm 0.47 \mathrm{a}$ & $1.83 \pm 1.12 \mathrm{ab}$ & $20.09 \pm 16.68 \mathrm{ab}$ & $6.26 \pm 6.38 \mathrm{a}$ & $4.18 \pm 2.44 \mathrm{ab}$ \\
\hline & $20-60$ & $7.09 \pm 1.33 \mathrm{a}$ & $1.60 \pm 0.053 \mathrm{a}$ & $8.57 \pm 0.47 \mathrm{a}$ & $1.79 \pm 1.41 \mathrm{ab}$ & $12.63 \pm 7.40 \mathrm{~b}$ & $3.39 \pm 6.07 \mathrm{a}$ & $2.56 \pm 0.79 b$ \\
\hline & $60-100$ & $4.74 \pm 1.41 \mathrm{~b}$ & $1.62 \pm 0.048 \mathrm{a}$ & $8.58 \pm 0.41 \mathrm{a}$ & $0.84 \pm 1.27 \mathrm{~b}$ & $13.46 \pm 6.20 \mathrm{~b}$ & $7.81 \pm 8.77 \mathrm{a}$ & $2.90 \pm 1.18 b$ \\
\hline \multirow{4}{*}{2012} & $0-5$ & $5.16 \pm 1.02 \mathrm{ab}$ & $1.40 \pm 0.16 \mathrm{a}$ & $8.42 \pm 0.48 \mathrm{a}$ & $10.82 \pm 2.64 \mathrm{a}$ & $25.21 \pm 10.15 \mathrm{a}$ & $6.10 \pm 5.71 \mathrm{a}$ & $42.03 \pm 27.77 \mathrm{a}$ \\
\hline & $0-20$ & $4.46 \pm 0.17 b$ & $1.36 \pm 0.15 \mathrm{a}$ & $8.56 \pm 0.49 \mathrm{a}$ & $2.16 \pm 1.20 \mathrm{~b}$ & $22.44 \pm 15.71 \mathrm{ab}$ & $5.82 \pm 4.54 \mathrm{a}$ & $35.17 \pm 10.98 \mathrm{a}$ \\
\hline & $20-60$ & $5.65 \pm 1.34 \mathrm{a}$ & $1.40 \pm 0.10 \mathrm{a}$ & $8.60 \pm 0.42 \mathrm{a}$ & $1.61 \pm 0.32 b$ & $18.19 \pm 5.82 \mathrm{ab}$ & $2.99 \pm 1.19 \mathrm{a}$ & $24.66 \pm 6.46 a$ \\
\hline & $60-100$ & $4.99 \pm 0.26 \mathrm{ab}$ & $1.42 \pm 0.12 \mathrm{a}$ & $8.60 \pm 0.45 \mathrm{a}$ & $1.70 \pm 1.27 b$ & $17.21 \pm 6.66 \mathrm{~b}$ & $1.84 \pm 0.38 \mathrm{a}$ & $22.92 \pm 4.89 \mathrm{a}$ \\
\hline \multirow{4}{*}{2019} & $0-5$ & $5.11 \pm 1.18 \mathrm{a}$ & $1.01 \pm 0.13 \mathrm{a}$ & $8.68 \pm 0.40 \mathrm{a}$ & $18.17 \pm 11.61 \mathrm{a}$ & $30.47 \pm 3.83 \mathrm{a}$ & $2.98 \pm 0.82 \mathrm{a}$ & $46.55 \pm 34.61 \mathrm{a}$ \\
\hline & $0-20$ & $4.44 \pm 0.19 \mathrm{a}$ & $0.96 \pm 0.11 \mathrm{a}$ & $8.79 \pm 0.42 \mathrm{a}$ & $2.42 \pm 1.45 b$ & $30.10 \pm 1.80 \mathrm{a}$ & $1.98 \pm 0.28 \mathrm{~b}$ & $38.01 \pm 13.55 \mathrm{a}$ \\
\hline & $20-60$ & $5.59 \pm 1.65 \mathrm{a}$ & $1.12 \pm 0.10 \mathrm{a}$ & $8.96 \pm 0.42 \mathrm{a}$ & $1.66 \pm 0.33 b$ & $28.17 \pm 3.50 \mathrm{a}$ & $2.10 \pm 0.33 \mathrm{~b}$ & $32.34 \pm 16.63 \mathrm{a}$ \\
\hline & $60-100$ & $2.12 \pm 0.38 b$ & $1.04 \pm 0.16 \mathrm{a}$ & $8.72 \pm 0.43 \mathrm{a}$ & $1.82 \pm 1.49 \mathrm{~b}$ & $26.29 \pm 3.75 \mathrm{a}$ & $2.47 \pm 0.40 \mathrm{ab}$ & $26.04 \pm 2.89 \mathrm{a}$ \\
\hline
\end{tabular}

Different lowercase letters indicate significant difference at $\mathrm{P}<0.05$ level. 
in $\mathrm{AN}, \mathrm{AP}$ and $\mathrm{AK}$ relative control area samples with the passage of time. Average rates of change in AN, AP and $\mathrm{AK}$ from different years since the subsidence event (Table 4) show clear decline. These results accord with those reported by Yao Guozheng et al. for Bulianta Coal Mine along the southern margin of Mu Us Sandy Land which showed similar trends in available nutrients from subsided areas [30]. In terms of their temporal variation, AN, AP and AK fluctuate sharply right after subsidence and then gradually stabilize with the passage of time. The relatively low values however suggest that the area could still benefit from soil and vegetation restoration.

This research addressed changes in soil physicochemical properties in a semi-arid area over a period of years since a subsidence event. Given its geography and climate, both natural and anthropogenic factors could also affect the study area.

\section{Conclusions}

This study monitored the soil physical and chemical properties over a period of years following a coal mine subsidence event. Soil moisture decreased with soil depth but increased with the passage of time since the subsidence event so as to generally return to initial levels prior to subsidence. The bulk density of soil from different depths did not vary significantly in a given monitoring year but SBD generally decreased with the passage of time since the subsidence event, as did SBD in control area samples. The average rate of change in bulk density for samples collected in different years ranked as: $2019<2006<2012$. These rates indicate that the SBD in subsided areas gradually returns to levels in the control areas.

Soil $\mathrm{pH}$ did not vary over different years $(\mathrm{P}>0.05$, Table 5). The SOM content measured in 2019 exceeded that measured in samples collected from other years $(\mathrm{P}<0.05$, Table 5). Samples from the surface ranked as: $2006<2012<2019$. The $0-5 \mathrm{~cm}$ layer samples consistently showed the highest AN, AP and AK measured over different years. These parameters all decreased with soil depth. Their coefficients of variation and average rate of change decreased with the passage of time. These results indicate that $\mathrm{AN}, \mathrm{AP}$ and $\mathrm{AK}$ tend to stabilize with the passage of time since the subsidence event.

\section{Acknowledgment}

This research was financially supported by the sub-project of Inner Mongolia Autonomous Region major scientific and technological program of Research on Soil Quality Evolution and Control Mechanism of Coal Resource Exploitation in Windstorm Area [zdzx2018058], the Inner Mongolia Natural Science Foundation Program of Study on the Influence Mechanism of Wind Power Station on Vegetation in Grassland Area of Northern, China [2018MS04009].

\section{Conflicts of Interest}

The authors declare no conflict of interest.

\section{Reference}

1. HU ZHENQI, XIAO WU, WANG PEIJUN, et al. Discussion on reclamation technology while mining in coal mine. Journal of China Coal Society, 38 (2), 301, 2013.

2. QIN HONG ZHENG. Study on soil environmental impact assessment in western ecologically fragile mining areas. Coal Engineering, 52 (8), 44, 2020.

3. HUIJUN REN, YUSHENG LIANG, YANG YU. Effect of Underground Fracture Mining on Soil Total Nitrogen in Windblown Sand Area. METAL MINE, 488 (2), 157, 2017.

4. ZHAO TONG. Discussion on Land Damage and Reclamation Technology of Coal Mining in Shenmu City. Southern Agriculture, 14 (8), 187, 2020.

5. REBECCA C., ROONEY, SUZANNE E., et al. Oil sands mining and reclamation cause massive loss of peatland and stored Proceedings of the National Academy of Sciences of the United States of America, 109 (13), 4933, 2012.

6. HUA LI, HONGBO SHAO, WEIXIANG LI, et al. Improving Soil Enzyme Activities and Related Quality properties of reclaimed soil by applying weathered coal in [3] Wang Y, Wang Y, Wang Y, et al. A new method of mining areas in the Qinghai-Tibet Plateau.Journal of China University of Geoscience and Remote Sensing, 23 (3), 233, 2012.

7. HU ZHENQI, WEI ZHONGYI, QIN PING The concept and method of soil reconstruction for mine reclamation. Soils, (1), 8, 2005.

8. GAO XIAOMEI Study on land ecological quality change and evaluation of coal mining subsidence area in $\mathrm{Mu}$ us Sandy Land [D]. Inner Mongolia Normal University, 2021.

9. XIE YUANGGUI, CHE JIAXIANG, SUN WENBO, et al. Contrastive study on soil physical properties of different coal mining subsidence years in coal mining area. Research of Soil and Water Conservation, 19 (4), 26, 2012.

10. LEI SHAOGANG Study on the monitoring of key environmental factors and the influence law of mining in desert mining area [D]. China University of Mining and Technology, 2009.

11. ZHANG FAWANG, HOU XIINWEI, HAN ZHANTAO, et al. Effects of coal mining collapse on soil quality and its protection technology. Geography and Geo-Information Science, (3), 67, 2003.

12. WANG SHUANGMING, DU HUADONG, WANG SHENGQUAN. Process and mechanism analysis of soil and vegetation damage in northern Shenmu coal mining subsidence area. Journal of China Coal Society, 42 (1), 17, 2017.

13. LIU ZHAOXIANG Research on reconstruction of geological environment in arid grassland area of Bulianta Coal Mine . Safety in Coal Mines, 48 (S1), 90, 2017.

14. SONG YAXIN Study on water transport and ecological environment effect in gaseous zone of Shenfu-Dongsheng coal mining subsidence area [D]. Chinese Academy of Geological Sciences, 2007.

15. YU DONGXUE, JIA XIAOXU, HUANG LIMING, et al. Spatial variation and simulation of soil bulk density 
in different soil layers in loess region. Acta Pedologica Sinica, 56 (1), 55, 2019.

16. QI YANLING, GUO LIWEN, LI FUPING, HUANG BAOZHU. Study on ecological security evaluation of coal mining subsidence area. Mine Surveying, (01), 56-59+68, 2005.

17. SCHMIDT M.G., MACDONALD S.E., ROTH WELL R.L. Impacts of harvesting and mechanical site preparation on soil chemical properties of mixedwood boreal boreal forest sites in Alberta. Canadian Journal of Soil Science, 76, 531, 1996.

18. ZHANG HONGWEI Spatial heterogeneity distribution and influencing factors of soil available N, P and K [D]. Tianjin Polytechnic University, 2016.

19. STOCK J.B., STOCK A.M., MOTTONEN J.M. Signal transduction in bacteria.Nature, 344 (6265), 395, 1990.

20. ZHOU RUIPING Effects of coal mining collapse on soil properties of aeolian sand in Ordos area [D]. Inner Mongolia Agricultural University, 2008.

21. CUI GAOYANG, RONG LI, LI XIAODONG, et al. Changes of soil physical and chemical properties in the process of controlling rocky desertification in the karst plateau. Chinese Journal of Ecology, 36 (5), 1188, 2017.

22. HU ZHENQI, XIAO WU, ZHAO YANLING Discussion on the Ecological Environment of Coal Mine Area "Mining while Recovering". Journal of China Coal Society, 45 (01), 351, 2020.

23. ZANG YINTONG, WANG JI, DING GUODONG, et al. Changes of physical and chemical properties of aeolian sand soil after coal mining subsidence and its evaluation. Acta Pedologica Sinica, 47 (2), 262, 2010.

24. HAN YU, SHI NANA, WANG QI, et al. Changes of soil physical and chemical properties in sandstorm area disturbed by coal mining collapse. Environmental Science and Technology, 39 (11), 15, 41, 2016.

25. LI LI, WANG YUEXIN, WANG WEIBIN Effects of coal mining collapse on soil physical and chemical properties of sloping farmland in loess hilly region. Chinese Journal of Soil Science, 41 (5), 1237, 2010.

26. WANG JIAN, GAO YONG, WEI JIANGSHENG, et al. Study on the influence of coal mining collapse on soil physical and chemical properties in sandstorm area. Journal of Soil and Water Conservation, (5), 52, 2006.

27. MOONEY H.A., VITOUSEK P.M., MATSON P.A. Exchange of materials between terrestrial ecosystems and the atmosphere. Science, 238 (4829), 926, 1987.

28. WANG QI, QUAN ZHANJUN, HAN YU, et al. Changes of soil physical and chemical properties in different recovery years of coal mining collapse in sandstorm area. Journal of Soil and Water Conservation, 28 (2), 118 , 126, 2014.

29. LIU MEIYING, GAO YONG, WANG JI, et al. Variation characteristics of soil carbon and nitrogen content in reclaimed land of mining area. Research of Soil and Water Conservation, 20 (1), 94, 101, 2013.

30. YAO GUOZHENG, DING GUODONG, ZANG YINTONG, et al. Evaluation of soil quality in windblown sand area of coal mining subsidence based on discrimination and factor analysis. Transactions of the Chinese Society of Agricultural Engineering, 28 (07), 200, 2012.

31. HE MINGHUI, GAO YONG, CHEN XI, et al. Effects of coal mining collapse cracks on soil available nutrients. Northern Horticulture, 312 (9), 186, 2014. 